\title{
Tree Species Composition in Tropical Forest Remnants of Highly Deforested Regions: The Case of the Huasteca Potosina Region, Mexico
}

\author{
Humberto Reyes, Blanca M. Vázquez, Carmen Jasso, Miguel Aguilar \\ Coordinación de Geografía, Facultad de Ciencias Socialesy Humanidades, Universidad Autónoma de San Luis \\ Potosí, San Luis Potosí, México

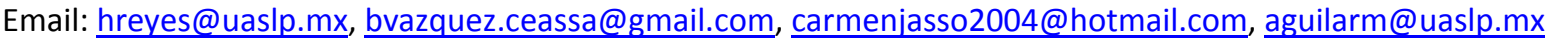

Received 27 September 2014; revised 11 November 2014; accepted 30 November 2014

Copyright (C) 2014 by authors and Scientific Research Publishing Inc.

This work is licensed under the Creative Commons Attribution International License (CC BY).

http://creativecommons.org/licenses/by/4.0/

(c) (i) Open Access

\begin{abstract}
Deforestation and fragmentation of tropical forest are the most serious threats to biodiversity. In the lowlands of the Huasteca Potosina region, Mexico, more than 95,000 ha of tropical forest have disappeared. This paper analyses tree species composition in tropical forest patches of this highly deforested region, located in northeast of Mexico. At present, only 57 remnants of arboreal vegetation larger than ten hectares still remain standing, which cover 6117 ha. These decreasing fragments host 140 floristic species, representing 42 families and 85 genera. Compared with previous inventories, these data show a sharp drop in species composition. Most of the forest remnants contain less than $\mathbf{5 0 \%}$ of the floristic diversity recorded by previous surveys, particularly in the medium subperennial tropical forest.
\end{abstract}

\section{Keywords}

Deforestation, Fragmentation, Forest Fragments, Huasteca Potosina, Mexico

\section{Introduction}

Tropical forests are the most important terrestrial biomes, which contain the greatest specific diversity known - in all, and host more than half animal and plant species of the planet [1]. However, these tropical forests are rapidly being converted to pasturelands and croplands [2]. Around the world, 292 million ha of tropical forests were logged between 2000 and 2005, and 248,000 ha of tropical forests disappeared from Central America during the last decade [3]. Deforestation and forest degradation caused by uncontrolled logging, human-set 
fires and other anthropogenic disturbances reduce the ecosystemic services provided by tropical forests which have severe consequences at different scales [4]-[6]. They are known as the main threats to biodiversity affecting $83 \%$ of all threatened mammals and $91 \%$ of threatened plants [4]. Additionally, deforestation leads to the fragmentation of formerly continuous forest habitats, decreased connectivity of the remaining vegetation, decreased patch sizes and increased distances between patches [7].

Mexico is one of the 17 mega-diverse countries and it is home to $10 \%-12 \%$ of the world's biodiversity [8], and the flora and fauna of Mexico are among the world's richest [1]. Unfortunately, in the last 30 years $10 \%$ of tropical forests in Mexico have disappeared [9]. Although the deforestation rate has decreased over the last decade, the country lost more than 155,000 ha of tropical and temperate forests per year, between 2005 and 2010 [3]. In particular, the lowlands of the Huasteca Potosina have been subject to an intense environmental transformation since the early 1970s when the federal government executed the Pujal-Coy hydro-agricultural project. This project implemented in three Mexican States (San Luis Potosí, Tamaulipas and Veracruz) covered more than 720,000 ha, where different types of tropical forest occupied $40 \%$ of this land. In the Huasteca Potosina, from 1973 to 1985 , more than 74,000 ha of tropical forests were cleared-with state funding — and converted to croplands and pasture lands [10]. In the face of this extreme tropical deforestation, ecosystems and several plants and animal species were widely affected.

By 2000, less than 11,000 ha of tropical forests were left standing and this patchy area contained only 71 forest relicts larger than 10 ha each (Figure 1). Notwithstanding their small extension, these remnants are the only persisting fragments representing the original tropical forest from the region. This is especially important since they function as buffer zones, small-scale in situ genetic repositories and biological corridors that facilitate genetic flow among wildlife populations. Understanding the dynamics of forest loss is crucial for the management and conservation of biodiversity [11], and thus promoting their conservation is necessary to know their history of land-use change and the species composition. Within this context, this paper analyses tree species composition in several remnants of tropical forest, identifies endangered species and advocates for immediate protective actions for these biodiversity remnants of tropical forest that still remain in the lowlands of the Huasteca Potosina region.

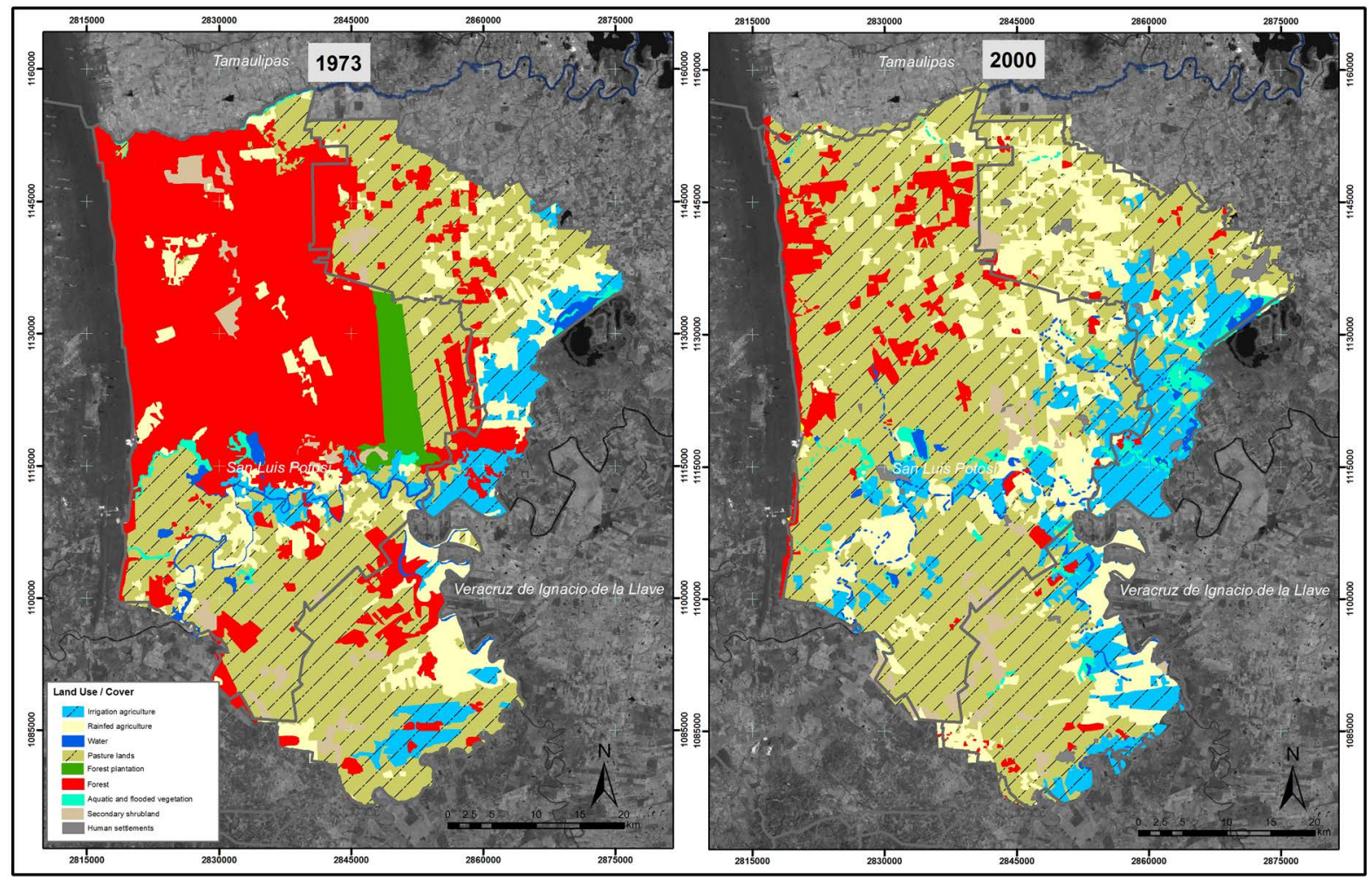

Figure 1. Forest cover transformation in the Huasteca Potosina lowlands 1973-2000. 


\section{Research Methods}

\subsection{Study Area}

The lowlands of the Huasteca Potosina region are located on the Gulf of Mexico coastal plain $\left(21^{\circ} 37^{\prime}\right.$ to $22^{\circ} 28^{\prime}$ $\mathrm{N}$ and $98^{\circ} 07^{\prime}$ to $98^{\circ} 50^{\prime} \mathrm{W}$ ); they cover about 305,600 ha and include the municipalities of Ébano, Tamuín and San Vicente Tancuayalab, in San Luis Potosí State (Figure 2). This region is a broad plain with gentle slopes towards the southwest; it includes small areas of low hills and scattered low mountains which stand away from the highlands, with altitudes varying from 100 to 150 m.a.s.l. and slopes from five to $15 \%$. The minimum altitude is 15 m.a.s.l. located in the flooding area where the Tampaón and Moctezuma rivers merge [12].

According to the modified Köppen's climate classification, the prevailing climate in the northern, central and western sections, which covers more than $85 \%$ of the study area, corresponds to a warm sub-humid climate with summer rainfall $\left(\mathrm{Aw}_{0}(\mathrm{e}) \mathrm{gw}\right.$ "). Towards the south, the climate is more humid and is classified as sub-humid with summer rainfall $\left(\mathrm{Aw}_{1}(\mathrm{e}) \mathrm{w}^{\prime \prime}\right)$. The region's rainfall pattern is characterized by a marked seasonality, with a short drought spell (canícula) amid the rainy season [12].

The vegetation types reported in the study region are tropical low thorn forest, the driest tropical forest characterized by lower canopy (less than 10 meters) and abundant thorny species. Tropical low dry deciduous forest whose main characteristic is deciduousness of most tree species, canopy between 10 and 30 meters, less dry than the previous one. Finally, the tropical medium semi-deciduous forest, the most humid is composed of semi-evergreen and deciduous tree species, canopy reaches 50 meters [13]-[16].

Concerning fauna, at least 17 different types of mammals have been reported [17] [18], such as jaguar (Panthera onca) (an endangered species protected in Mexico since 1987), ocelot (Leopardus pardalis), tree ocelot (Leopardus wiedii); cougar (Puma concolor), tepezcuintle (Agouti paca); white-tailed deer (Odicoileus virginianus); red brocket deer (Mazama americana) and white-lipped peccary (Tayassu pecarî).

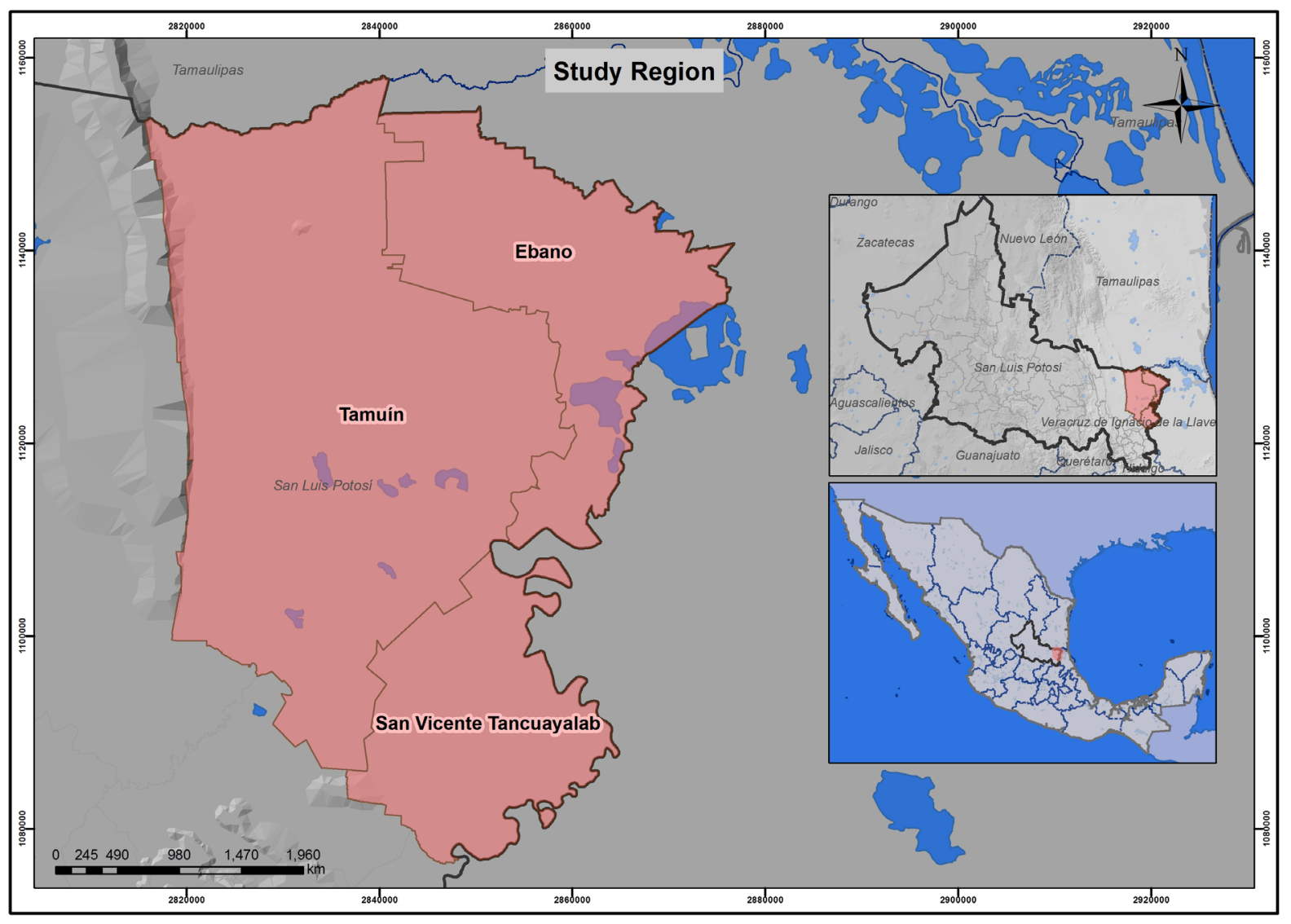

Figure 2. The lowlands of the Huasteca Potosina region, Gulf of Mexico coastal plain. 


\subsection{Estimates of Forest Changes}

Based on the location of 71 woody vegetation fragments identified in the year 2000 [10] (Figure 3), the limits, size and presence of these forest remnants were updated to 2008. To do so, three 2008 satellite SPOT images (588/306, 588/307, 589/307 KJ) were analyzed with a false color composition using bands 5, 4 and 3. The digital layer of 71 fragments was superimposed on the SPOT images and the polygons were demarcated directly on the computer screen. The version 9.2 of ArcGIS software was used for this purpose.

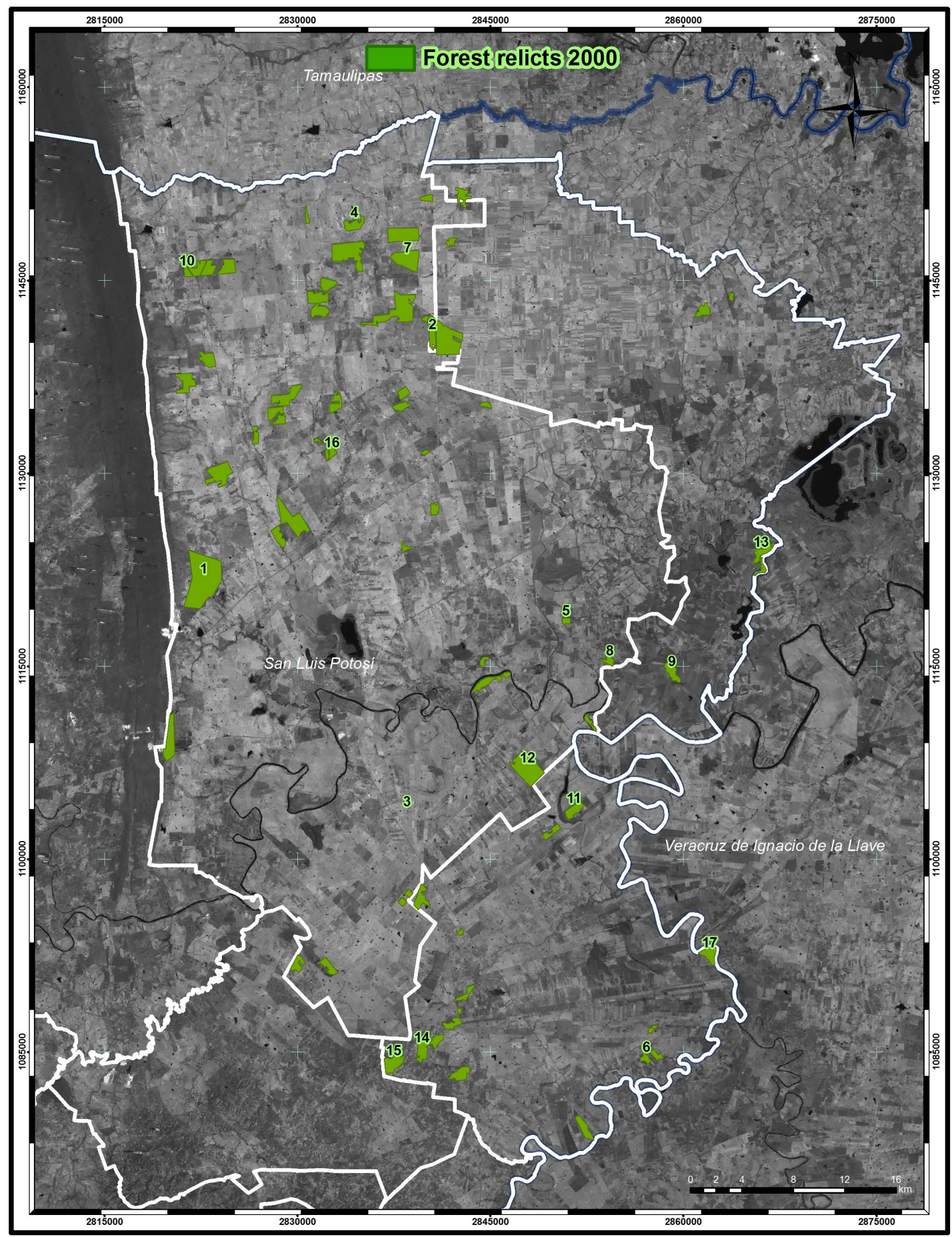

Figure 3. Forest fragments larger than 10 ha in the lowlands of the Huasteca Potosina region in year 2000. 
The deforested relicts registered in 2000 were eliminated and those relicts that were identified as standing fragmented were divided into smaller polygons. The divided or reduced fragments were delimited again, and their re-calculated area was used to calculate the total area of forest remnants. The annual rate of change of forest cover was calculated using the compound-interest-rate formula due to its explicit biological meaning [11]:

$$
P=100 / t_{2}-t_{1} \operatorname{In} A_{2} / A_{1}
$$

where: $P$ is the annual percentage of forest loss $A_{1}$ and $A_{2}$ are corrected forest cover estimates at time $t_{1}$ and $t_{2}$, respectively [7] [11].

\subsection{Inventory of Trees and Forest Structure}

For this purpose, 36 fragments representative of the three main vegetation types (tropical low thorny forest, tropical low dry deciduous forest, and tropical medium semi-deciduous forest) with area $\geq 10$ ha were selected randomly. Based on physical accessibility to each fragment and with its owner's consent, 17 of them were selected to undertake the inventory of trees and shrubs.

In the field, within each fragment, $0.5 \mathrm{~km}$ transects were established. One observation point was established at one tip of each transect and all woody species observed (trees, shrubs) around this point (in a circular area with $10 \mathrm{~m}$ radius) were identified and quantified. The number of observation points depended on the vegetation changes within each fragment and its extent. On average, six transects per fragment were established (108 for all the measured fragments).

In order to determine the structure and age of the vegetation, measurement of tree diameter at breast height (DBH) was done for all observed species. The inventory also included the gathering of six samples of each woody species. Tree species were identified by a local expert botanist, and their vernacular/common names were recorded. Scientific names were determined for all collected tree species by comparing them with previous botanical inventories and consulting of species lists reported by Miranda \& Hernández X [13]; Rzedowski [14]; Puig [16] and Pennington \& Sarukhán [19] for the study region.

Complementary information such as disturbance degree (for example, tree felling frequency, livestock foraging and firewood extraction), predominant environmental conditions (relief, slope, and soil type) and land-use history of each fragment, was collected for its characterization.

Woody species that could not be identified in the field were collected, labeled, pressed, and then taken to the "Isidro Palacios" Herbarium at the Research Institute of Arid Lands, Autonomous University of San Luis Potosí (IIZD-UASLP) for later ex situ identification. The eventual floristic identification was carried out following this procedure: 1) matching common and scientific names as previously determined by botanists, 2) dichotomous keys, representing two incompatible set of characters, 3) collection of specimens previously identified in book reviews/inventories, and 4) direct identification by local experts.

Of the samples, 81 were determined to the species level, 22 to genus level, 18 identified just by common name and 19 species were not determined due to the lack of reproductive organs.

Finally, the endangered tree species were identified through direct review of the Mexican Official Norm (NOM 059-SEMARNAT-2010), related to the protection of native species in Mexico. The environmental law classifies the endemic species in four categories: a) endangered, b) threatened, c) special protection, and d) probably extinct.

\section{Results}

Results show that there were 57 woody vegetation fragments larger than 10 ha in 2008, namely 14 less than in 2000. The mean size of forest fragments decreased from 110 ha in 2000 to 86 ha in 2008, as well as their perimeter (5050 $\mathrm{m}$ to 4480 ) in the same period. It is important to note that five of them ( $\geq 100 \mathrm{ha}$ ), were fragmented into 13 relicts with an area $\leq 20$ ha. At least eight were reduced more than $40 \%$ from its original size such as (15) San Francisco Cuayalab, (4) El Jaguar and (9) La Reforma, which further increased the fragmentation of the dry tropical forests still remaining in the lowlands of the Huasteca Potosina (Figure 4).

The real impact of deforestation can be found in the overall decrease in area of forest fragments (31 of them were reduced from 7786 to 6117 ha in 2008, 1669 ha less than in 2000). The deforestation rate calculated for the 2000-2008 period was $2.9 \%$ per year. At the same time, just four fragments increased in size. According to average diameter of trees and land-use history of each fragment, 13 belong to primary vegetation and four to 


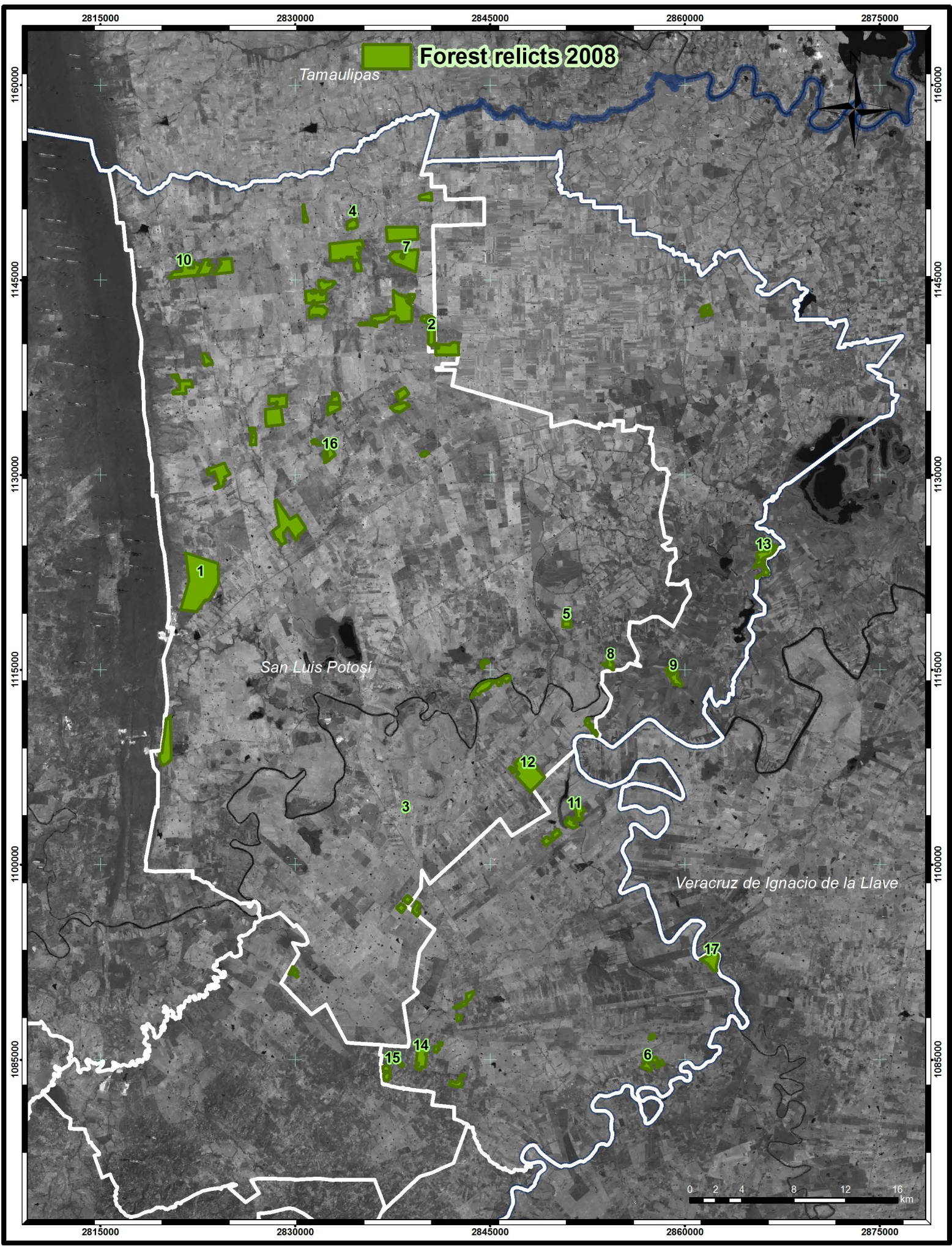

Figure 4. Forest fragments larger than 10 ha in the lowlands of the Huasteca Potosina region in year 2008.

secondary woody vegetation. The trees found in the last remaining fragments grew up in previously cleared lands for the Pujal-Coy hydro-agricultural project, but later abandoned by farmers. 
In total, 140 different trees species were found in the fragments analyzed. These species belong to 42 families and 85 genera. Out of the collected species, 103 were trees and 37 were shrubs. Based on the identified species in each fragment, it was determined that five correspond to the tropical medium semi-deciduous forest (MSDF), eleven to the tropical low dry deciduous forest (LDDF), and two to tropical low thorny forest (LTF) (Table 1).

In the low tropical thorny forest relicts, only seven tree species were registered which results in a poor floristic richness and the complete absence of thorny species, the presumed salient feature of this type of vegetation. The arboreal stratum is dominated by species such as: Tabernaemontana alba Mill., Bauhinia divaricata L., Pithecellobium calostachys Standl., Sabal mexican Mart, Ziziphus obtusifolia (Hook. ex. Torr \& Gray) A. Gray, Celtis sp. and Guazuma ulmifolia Lam. (Table 1).

In the low tropical deciduous forest relicts, 75 different tree species were registered. The dominant species were: Senna atomaria (L.) H. S. Irwin \& Barneby, Achatocarpus nigricans Triana, Colubrina elliptica (Sw) Briz. \& W. L. Stern, Euphorbia schendallii Boiss, Phyllostylon brasiliensis Capan, Acacia sp., Randia aculeata L., Ruprechtia cumingii Meisn., Guazuma ulmifolia Lam., Pithecellobium sp. and Sebastiana sp. (Table 1).

In tropical medium semi-deciduous forest relicts, 57 different tree and shrub species were registered. The dominant tree species in the upper stratum were: Spondias sp., Tabernaemontana alba Mill., Ceiba pentandra (L.) Gaertn, Bursera simaruba (L.) Sarg., Garcia nutans Rhor, Acacia sp., Harpalyce arborescens A. Gray, Pithecellobium sp., Trichilia havanensis Jacq., Brosimun alicastrum Sw., Ficus sp., Piper sp., Coccoloba montana Standl., Ruprechtia cumingii Meisn., Randia aculeata L., Salix humboldtiana Willd., Populus arizonica Sarg., Pouteria durlandii (Standl.) Baehni, Guazum aulmifolia Lam., Carpodiptera ameliae Lundell. The dominant species in the medium stratum of the same forest were: Yucca sp. Enterolobium cyclocarpum (Jacq.) Griseb., Parmentiera aculeata (Kunth) Seem. and Tabebuia rosea (Bertol) DC (Table 1).

Four forest fragments (1) CEMEX, (15) San Francisco Cuayalab, (4) El Jaguar and (11) Los Fomentos have at least more than 30 species, in contrast with (13) Pozos de Petróleo, (17) Tancojol and (3) El Hermanito where we found less than eight species in each fragment. Only one species (Cedrela odorata L.) found in San Francisco Cuayalab is under special protection according to NOM-059 for the protection of native species.

Table 1. Characteristics of the forest fragments of the lowlands Huasteca Potosina.

\begin{tabular}{|c|c|c|c|c|c|c|}
\hline $\begin{array}{l}\text { ID/Owner/Name of } \\
\text { reference village }\end{array}$ & $\begin{array}{c}\text { Type of } \\
\text { vegetation }\end{array}$ & $\begin{array}{c}\text { Surface ha in } \\
2000\end{array}$ & $\begin{array}{l}\text { Surface ha } \\
\text { in } 2008\end{array}$ & Current status & $\begin{array}{l}\text { Total of } \\
\text { species }\end{array}$ & $\begin{array}{c}\text { Density } \\
\text { species/ha }\end{array}$ \\
\hline (1) CEMEX & LDDF & 862 & 862 & No change & 48 & 5133 \\
\hline (2) Crucero-Crucerito & LDDF & 70 & 59 & 21 ha less & 24 & 2181 \\
\hline (3) El Hermanito & MSDF & 23 & 23 & No change & 7 & 386 \\
\hline (4) El Jaguar & LDDF & 101 & 47 & 54 ha less & 33 & 2610 \\
\hline (5) El Porvenir & LDDF & 29 & 29 & No change & 26 & 485 \\
\hline (6) El Sasub & MSDF & 37 & 37 & No change & 13 & 279 \\
\hline (7) El Tulillo & LDDF & 249 & 238 & 11 ha less & 11 & 271 \\
\hline (8) Jose I. Nava & LTF & 46 & 36 & 10 ha less & 20 & 224 \\
\hline (9) La Reforma & LDDF & 103 & 77 & 26 ha less & 15 & 350 \\
\hline (10) Las Norias & LDDF & 158 & 158 & No change & 29 & 2646 \\
\hline (11) Los Fomentos & LDDF & 100 & 99 & 1 ha less & 31 & 1051 \\
\hline (12) Nuevo Ahuacatitla & LDDF & 373 & 354 & 19 ha less & 14 & 492 \\
\hline (13) Pozos de Petróleo & LTF & 99 & 99 & No change & 7 & 171 \\
\hline (14) Rancho Jumaisa & MSDF & 144 & 131 & 13 ha less & 20 & 160 \\
\hline $\begin{array}{l}\text { (15) San Francisco } \\
\text { Cuayalab }\end{array}$ & MSDF & 160 & 63 & 97 ha less & 34 & 395 \\
\hline (16) San Juan 1 & LDDF & 39 & 39 & No change & 14 & 1000 \\
\hline (17) Tancojol & MSDF & 100 & 100 & No change & 8 & 532 \\
\hline
\end{tabular}

Type of vegetation: Tropical low thorn forest (LTF); Tropical low dry deciduous forest (LDDF); Tropical medium semi-deciduous forest (MSDF). 


\section{Discussion}

Deforestation process in the Huasteca Potosina lowlands, that started 40 years ago, is still ongoing. Evidences show that the last forest remnants lost 1669 ha in eight year (2000/2008). This region had one of the highest deforestation rates (11\% per year) in Mexico between 1973 and 1985, due to the implementation of the Pujal-Coy irrigation project (Figure 1). One of the major impacts of the Pujal-Coy irrigation project was the landscape transformation, because in order to grant totally cleared lands, state-funded bulldozers, track loaders and other heavy machines were used to remove tropical forest as fast as the new colonists arrived to settle the project area [12].

This explains why only seven predominant tree species were found in the Tancojol fragment corresponding to tropical medium semi-deciduous forest (Table 1), whereas field surveys conducted during the 1960s registered 17 dominating vegetation species in this type of forest [14]. Additionally, 85\% of the fragment is dominated by Guazuma ulmifolia Lam., an invader, fast-growing tree species that replaced the original species. In other words, this fragment shows not only a significant reduction of floristic diversity, but also a change in the predominant floristic composition (Table 1, Figure 4).

Intensification of agriculture, livestock and forestry is heavily transforming this landscape and it is considered one of the main drivers of changes in species composition of ecosystems [20]. Even though the intensity of the forest transformation shows a significant decrease compared to previous years, the increase in the fragmentation of these ecosystems is evident. In this sense, habitat fragmentation is one of the most serious threats to plant biodiversity at the within-population level [21].

Ecological changes are two-fold. On the one hand, although most forest fragments still have the same area compared to 2000, most of them show a poor tree density. On the other hand, some smaller fragments $(\leq 40$ ha) have more trees species than the larger ones. This is the case of the (5) El Porvenir and (6) El Sasub fragments where a greater diversity of species was found despite their small size (Table 1, Figure 4, Figure 5). The reason could be that these forest fragments are protected by agreements reached and enforced by local communities, that forbid firewood and timber collection.

One of the explanations of the poor floristic diversity found in the low tropical thorny forest relicts is that the

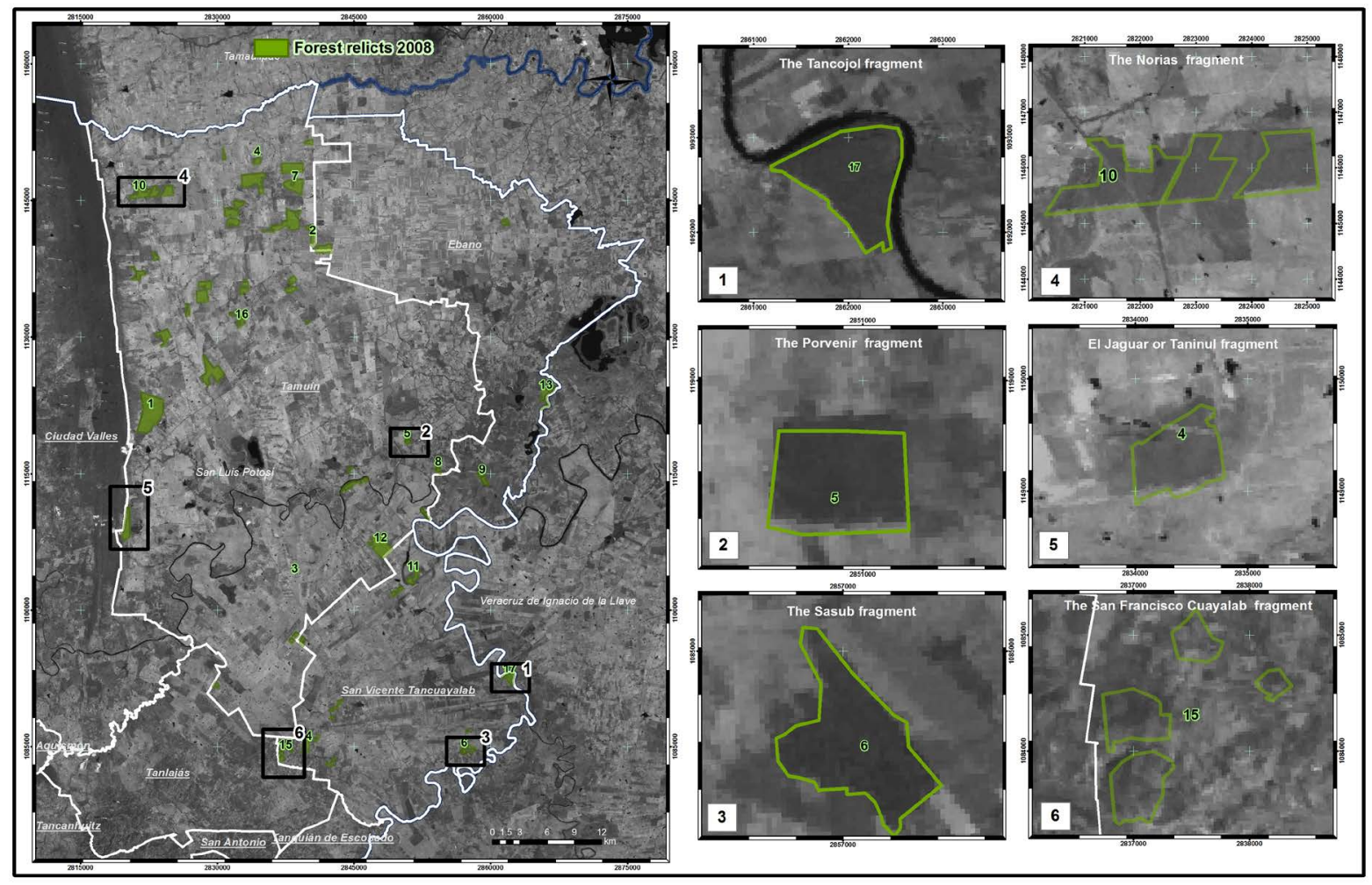

Figure 5. Detail of six forest fragments in the lowlands of the Huasteca Potosina region. 
tree and shrub strata were colonized by more aggressive species that established faster than the native vegetation. Species such as Phoebe tampicensis Mez. and Pithecellobium flexicaule (Benth.) J. M. Coult, are found in the low tropical thorny forest fragments only sporadically and as a part of the shrubby stratum, but previous studies [15] [16] [19] identified both species as dominating in the arboreal stratum in this vegetation type.

Rzedowski [14] and Puig [16] have pointed out that the disturbance of tropical deciduous forests facilitates the arrival and thriving of opportunistic species like Croton niveus Jacq., Karwinskiahum boldtiana (Roemer \& Shultes) Zucc., Sabal mexicana Mart., Guazuma ulmifolia Lam., and Piscidia piscipula (L.) Sarg., which proved to be very abundant in fragments where extensive cattle raising and selective tree cutting are common practices, such as the (3) El Hermanito, (13) Pozos de Petróleo and (16) San Juan 1.

Sabal mexicana is abundant where human set fires are common practice. The predominance of Cordia dentata Poiret., C. pringlei Robins., Croton sp., Harpalyce arborescens A. Gray and Rhacoma affscoparia, provide evidence of how these opportunistic species have substituted original species, facilitated by human-caused disturbance. The extraction of timber species or those with commercial value for local people has also modified the original composition and structure of vegetation.

Currently, most remnants of the low tropical deciduous forest contain less than $50 \%$ of the floristic diversity recorded by previous surveys conducted by Miranda \& Hernández X. [13]; Rzedowski [14] [15] and Puig [16]. In the medium tropical semi-deciduous forest, only eight floristic genera match with old registers, this represents only $20 \%$ of the native or endemic species from this vegetation community (Table 1). Ecosystem resilience depends greatly on biodiversity of organisms present [22] [23]. Depending on the level of disruption, a habitat will be modified not only in terms of its vegetal structure, but also in terms of its floristic complexity and heterogeneity [7].

In addition, it is postulated that physical and structural characteristics, dominating shapes, forest productivity and seasonality have a great influence on distribution and abundance of wildlife [5]. For instance, several large animal species have already become extinct in the region as a result of deforestation, fragmentation and forest degradation caused by uncontrolled logging, fires, extensive cattle raising and other anthropogenic disturbances. Grass et al. [20] point out that half of all organisms (plants, animals and microorganisms) living on earth might disappear at the end of the 21st century.

The last standing forest remnants are an important reservoir of regional biodiversity in spite of their precarious conditions. If they were not protected in a short time, they will disappear forever, along with their associated biodiversity. Even though there are two state-protected natural reserves near to a biosphere reserve, it is still necessary to look for other legal ways of protection for these forest fragments. Some of the woody vegetation fragments work as small-scale biological corridors, which still make possible both the in-situ germplasm conservation and allow the survival of vanishing wild animal populations.

It is also possible that private fragments, such as (10) Las Norias or (4) El Jaguar, could be converted into Units for Environmental Management (UMA), specifically for wildlife conservation, as long as their owners are willing to become part of this environmental venture. Although one species under special protection was found in the (15) San Francisco Cuayalabremnant (Cedrela odorata L.) under special protection according to NOM059, it is practically impossible to propose a strategy of protection because this forest relict was divided among the several owners (ejidatarios) and fragmented after the vegetation sampling finished (Figure 5). This conveys an idea of why immediate protective actions should be undertaken.

\section{Conclusion}

Although the deforestation process in the study region shows a significant decrease compared to previous years, the fragmentation still prevails. In eight years 14 forest fragments larger than 10 ha disappeared and their mean size and perimeter decreased, it means 1669 ha less than 2000. Overall, deforestation, extensive cattle raising, selective tree cutting, and opportunistic species invasion hamper the natural regrowth and expansion of forest remnants. These factors have caused a significant reduction of the tropical low thorny forest that once occupied a larger extent of this region. Furthermore, current floristic surveys, compared to previous studies, show an important decrease of tree species in the tropical deciduous forest. The 57 last standing forest remnants are an important reservoir of regional biodiversity, some of which are small-scale biological corridors, which still make the in-situ germplasm conservation possible and allow the survival of wild animal populations in spite of the prevailing conditions. The significant impact of deforestation in the composition and diversity of species of 
tropical low, thorny, and medium deciduous forests, force to look for legal ways of protection for the fragments that are still in good condition, otherwise they will disappear forever from the lowlands of the Huasteca Potosina.

\section{Acknowledgements}

We thank local botanist for help during the fieldwork, Tim Frazier and Augustine Avwunudiogba for their language correction as well as Laura Cano, Carlos Muñoz and Patricia Solis for their comments to improve the quality of this manuscript. The authors thank the Secretaría de Marina (SEMAR) for providing satellite images, FOMIX-SLP (FMSLP-2002-5715) and MyCOE-AAG (2007) (Biodiversity Initiatives in Central America) for providing the funds required to carry out the project.

\section{References}

[1] Puig, H. (2001) Diversité spécifique et déforestation: l'exemple des forets tropicales humides du Mexique. Bois et Forêts des Tropiques, 268, 41-55. http://dx.doi.org/10.1080/028418501127346846

[2] Dirzo, R. (2001) Tropical Forest. In: Chapin III, F.S., Sala, E.O. and Huber-Sannwald, E., Eds., Global Biodiversity in a Changing Environment Scenarios for the 21st Century, Springer-Verlag Inc., New York, 251-275. http://dx.doi.org/10.1007/978-1-4613-0157-8_12

[3] FAO (2010) Global Forest Resources Assessment. Food and Agriculture Organization, Rome.

[4] Sasaki, N., Asner, G.P., Knorr, W., Durst, P.B. and Priyadi, H.R. (2011) Approaches to Classifying and Restoring Degraded Tropical Forest for the Anticipated REDD+ Climate Change Mitigation Mechanism. iForest, 4, 1-6. http://dx.doi.org/10.3832/ifor0556-004

[5] McKinney, M.L. (1999) High Rates of Extinction and Threat in Poorly Studied Taxa. Conservation Biology, 13, 12731281. http://dx.doi.org/10.1046/j.1523-1739.1999.97393.x

[6] Armstrong, A.H., Shugart, H.H. and Fatoyimbo, T.E. (2011) Characterization of Community Composition and Forest Structure in Madagascar Lowland Forest. Tropical Conservation Sciences, 4, 428-444.

[7] Cayuela, L., Benayas, J.M.R. and Echeverria, C. (2006) Clearance and Fragmentation of Tropical Montane Forest in the Highlands of Chiapas, México (1975-2000). Forest Ecology and Management, 226, 208-2018. http://dx.doi.org/10.1016/j.foreco.2006.01.047

[8] Villaseñor, J.L., Ibarra-Manríquez, G., Meave, J.A. and Ortíz, E. (2005) Higher Taxa as Surrogates of Plant Biodiversity in a Megadiverse Country. Conservation Biology, 19, 232-238. http://dx.doi.org/10.1111/j.1523-1739.2005.00264.x

[9] OECD (2013) OECD Environmental Performance Reviews: Mexico 2013. OECD Publishing, Paris. http://dx.doi.org/10.1787/9789264180109-en

[10] Reyes-Hernández, H., Aguilar-Robledo, M., Aguirre-Rivera, J.R. and Trejo-Vázquez, R.I. (2006) Cambios en la cubierta vegetal y uso del suelo en el área del Proyecto Pujal-Coy, San Luis Potosí, México. Investigaciones Geográficas, 59, 26-42.

[11] Puyaravaud, J.P. (2003) Standardizing the Calculation of Annual Rate of Deforestation. Forest Ecology and Management, 177, 593-596. http://dx.doi.org/10.1016/S0378-1127(02)00335-3

[12] Reyes, H., Aguilar-Robledo, M., Aguirre, J.R. and Fortanelli, J. (2008) Spatial Configuration of Land-Use/Land-Cover in the Pujal-Coy Project Area, Huasteca Potosina Region, Mexico. Ambio, 37, 381-389.

[13] Miranda, F. and Hernández, X.E. (1963) Los tipos de vegetación de México y su clasificación. Boletín de la Sociedad Botánica de México, 28, 29-179.

[14] Rzedowski, J. (1966) Vegetación del estado de San Luis Potosí. Tesis Doctoral, UNAM, Mexico City.

[15] Rzedowski, J. (1986) Vegetación de México. Editorial Limusa, México.

[16] Puig, H. (1976) Tipos de Vegetación de la Huasteca Potosina (México). Instiut de Recherche pour le developpement en cooperation y Centro de Estudios Mexicanos y Centroamericanos, México.

[17] García-Marmolejo, G., Chapa-Vargas, L., Huber-Sannwald, E., Weber, M., Rosas-Rosas, O.C. and Martínez-Calderas, J. (2013) Potential Distributional Patterns of Three Wild Ungulate Species in a Fragmented Tropical Region of Northeastern Mexico. Tropical Conservation Science Journal, 6, 539-557.

[18] Hernández-Saint Martin, A.D., Rosas Rosas, O.C., Palacio Núñez, J., Tarango Arambula, J.L., Clemente Sánchez, F. and Hoogesteijn, A.L. (2013) Activity Patterns of Jaguar, Puma and Their Potential Prey in San Luis Potosi, Mexico. Acta Zoológica Mexicana, 29, 520-533. 
[19] Pennington, T.D. and Sarukhán, J. (1998) Árboles Tropicales de México. Fondo de Cultura Económica, México.

[20] Grass, A., Tremetsberger, K., Hössinger, R. and Bernhardt, K.G. (2014) Change of Species and Habitat Diversity in the Pannonian Region of Eastern Lower Austria over 170 Years: Using Herbarium Records as a Witness. Natural Resources, 5, 583-596. http://dx.doi.org/10.4236/nr.2014.511051

[21] Piotti, A. (2009) The Genetic Consequences of Habitat Fragmentation: The Case of Forest. iForest, 2, 75-76.

[22] Hooper, D.U., Chapin, F.S., Ewel, J.J., Hector, A., Inchausti, P., Lavorel, S., Lawton, J.H., Lodge, D.M., Loreau, M., Naeem, S., Schmid, B., Setälä, H., Symstad, A.J., Vandermeer, J. and Wardle, D.A. (2005) Effects of Biodiversity on Ecosystem Functioning: A Consensus of Current Knowledge. Ecological Monographs, 75, 3-35. http://dx.doi.org/10.1890/04-0922

[23] Cardinale, B.J., Srivastava, D.S., Duffy, J.E., Wright, J.P., Downing, A.L., Sankaran, M. and Jouseau, C. (2006) Effects of Biodiversity on the Functioning of Trophic Groups and Ecosystems. Nature, 443, 989-992. http://dx.doi.org/10.1038/nature05202 
Scientific Research Publishing (SCIRP) is one of the largest Open Access journal publishers. It is currently publishing more than 200 open access, online, peer-reviewed journals covering a wide range of academic disciplines. SCIRP serves the worldwide academic communities and contributes to the progress and application of science with its publication.

Other selected journals from SCIRP are listed as below. Submit your manuscript to us via either submit@scirp.org or Online Submission Portal.
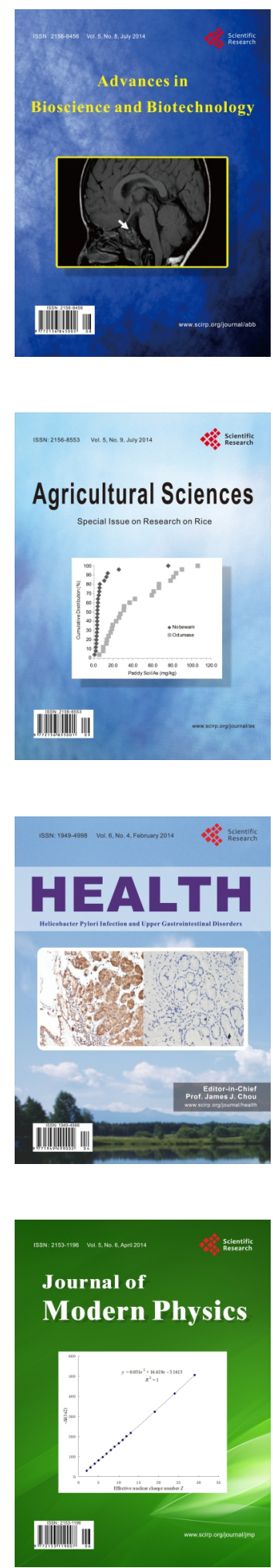
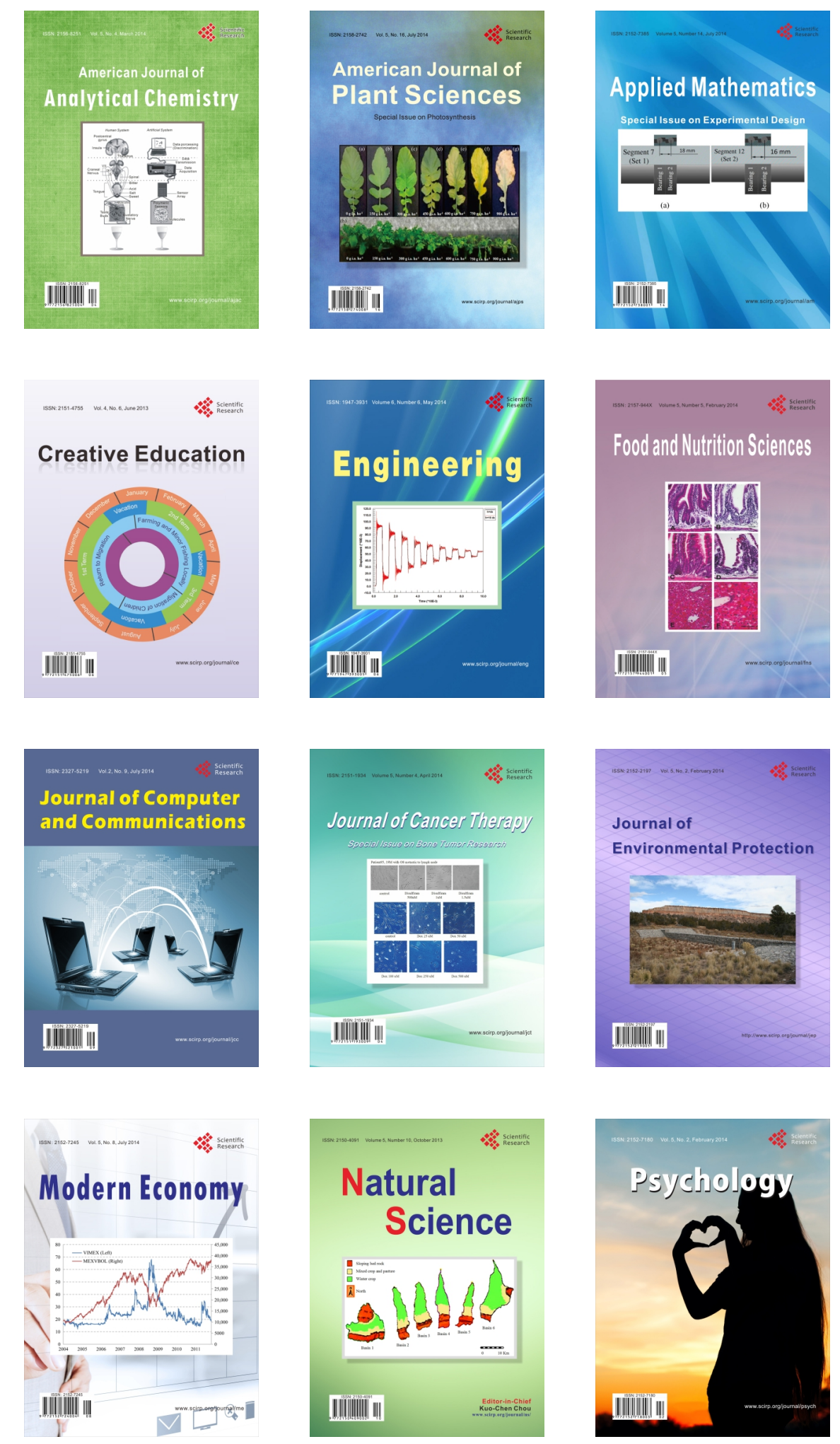